This item was submitted to Loughborough's Research Repository by the author.

Items in Figshare are protected by copyright, with all rights reserved, unless otherwise indicated.

\title{
Measuring the changes to leader brand associations during the 2010 election campaign
}

PLEASE CITE THE PUBLISHED VERSION

http://dx.doi.org/10.1080/0267257X.2011.587825

PUBLISHER

Taylor and Francis / @ Westburn Publishers Ltd

VERSION

AM (Accepted Manuscript)

LICENCE

CC BY-NC-ND 4.0

REPOSITORY RECORD

Smith, Gareth, and Alan French. 2019. "Measuring the Changes to Leader Brand Associations During the 2010 Election Campaign”. figshare. https://hdl.handle.net/2134/14789. 
This item was submitted to Loughborough's Institutional Repository (https://dspace.lboro.ac.uk/) by the author and is made available under the following Creative Commons Licence conditions.

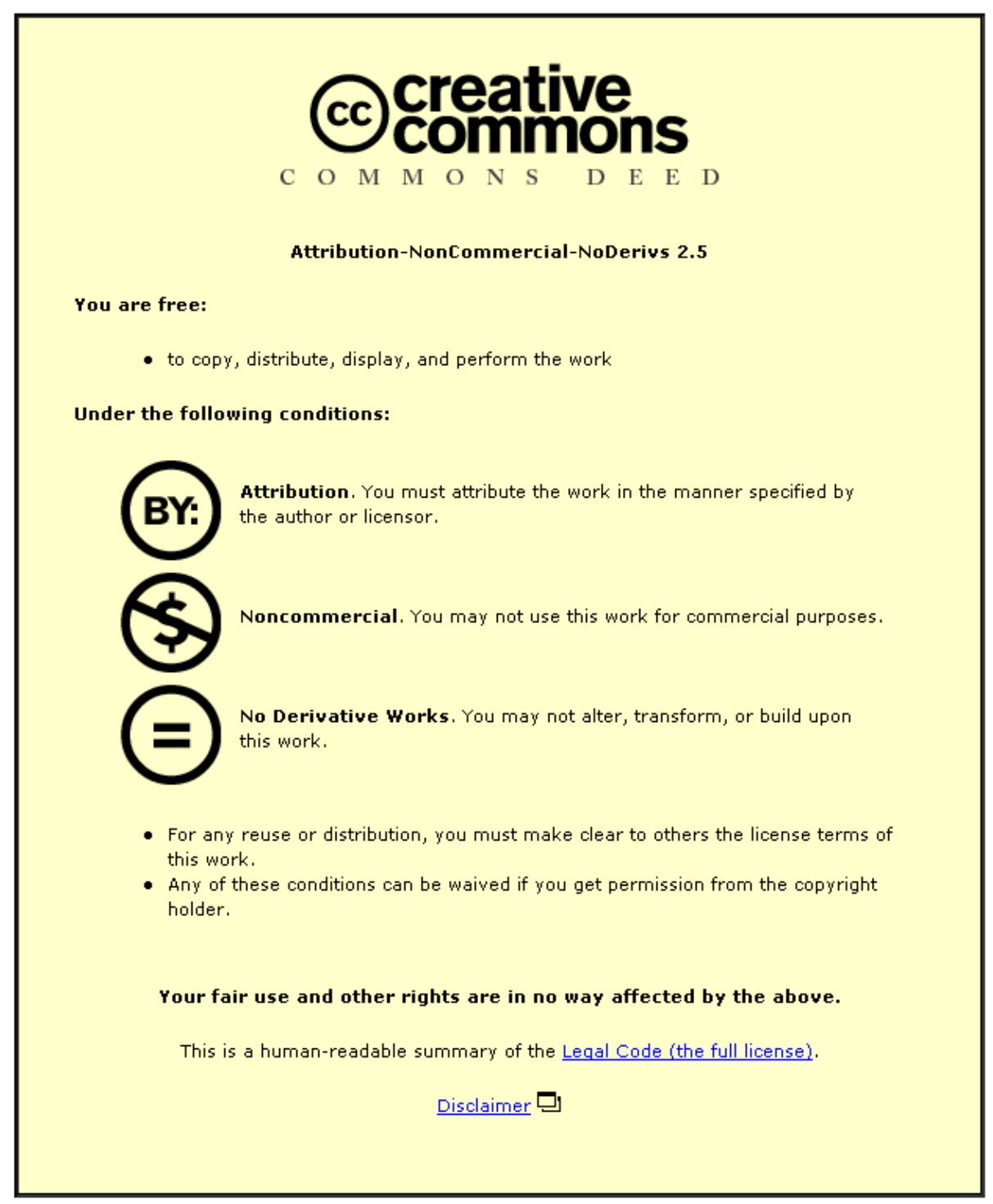

For the full text of this licence, please go to: http://creativecommons.org/licenses/by-nc-nd/2.5/ 
Measuring the Changes to Leader Brand Associations During the 2010 Election Campaign.

Gareth Smith $^{* \dagger}$ and Alan French ${ }^{* *}$

*Oxford Brookes University, UK.

** Loughborough University, UK.

${ }^{\dagger}$ Corresponding author:

Dr Gareth Smith, Professor of Marketing, Oxford Brookes University, Oxford, Oxfordshire OX33 1HX.

Tel: +44 (0)1865 485858, fax: +44 (0)1865 485830; email: g.smith@brookes.ac.uk 


\title{
Measuring the Changes to Leader Brand Associations During the 2010 Election Campaign.
}

\begin{abstract}
The 2010 UK General Election was unique in that for the first time televised leaders' debates took place. The impact of these plus paid for advertising and uncontrolled events are considered and their likely affect on the image of Brown, Cameron and Clegg, the three main party leaders, discussed. Then, using a brand mapping approach, we analyse changes to consumer perceptions of the leader brands from just prior to the first debate through to the election day itself, Thursday May $6^{\text {th }}$.

Specifically, we consider whether, over the campaign, the number of leader associations increases, which policies were associated with which leader and the favourability of the leaders associations. We then use a measure of brand image strength to chart overall changes to the leaders. Finally we consider how Brown's image was affected by the so called 'Duffy' affair.
\end{abstract}

Keywords: Brand Image Strength, Brand Concept Mapping, Politics, General Election.

Gareth Smith is a Professor in Marketing at Oxford Brookes University, UK. His research in branding covers brand personality, brand extension effects and branding in political markets. He has published on branding in the Journal of Marketing Management, European Journal of Marketing, Marketing Theory and Journal of Political Marketing.

Alan French is a Lecturer in Management Science at Loughborough University, UK. He studied for his first degree and $\mathrm{PhD}$ at the University of East Anglia. His research focuses on the application of Management Science techniques in business and he has published in the European Journal of Marketing, Journal of the Operational Research Society and Computers and Operations Research. 


\section{Measuring the Changes to Leader Brand Associations During the 2010 Election Campaign.}

\section{Introduction: Consumer Learning of Political Brands}

There has been a steady stream of papers that have accepted UK political parties and or politicians as brands (Kavanagh, 1995; Harris \& Lock, 2001; Smith, 2001; White \& de Chernatony, 2002; Needham, 2005, 2006; Scammell, 2007). More recently, a consumer oriented approach to political branding has developed (Schneider, 2004; Smith \& French, 2009; French \& Smith, 2010). This approach accepts that voters are involved in the same cognitive and affective processes that they use and apply when choosing what are traditionally thought of as brands.

The majority of the consumer-oriented research on brands (see Keller, 2002 for an overview) uses cognitive psychology and the human associative memory (HAM) model to conceptualise how consumers learn about brands (Teichert \& Schöntag, 2010). Brand learning is stored in memory as individual pieces of information or nodes which are linked together in memory to form a more complex associative network (Anderson, 1983). Importantly, a brand node may be activated from memory when one association stimulates the recall of another, linked node of information (de Groot, 1989). So, for example, the name Gordon Brown may activate associations such as Labour, Prime Minister, Chancellor, the economy and so on. It is this spreading activation process from a brand name to brand associations which produces a mental map in voters’ memory (Dobni \& Zinkman, 1990).

Using the extant literature as a guide, we propose several learning effects that are predicted to occur from the campaign. We then use primary research for evidence to support/negate these propositions. Specifically, we measured the associative brand networks of party leaders by using a brand mapping method; this was to reveal how the associations held of party leaders evolved during the 2010 Election Campaign. As voter maps are networks of associations about a party leader, we use network analysis to analyse them. This allows us to measure the leader image at the beginning and end of the campaign. We asked respondents with a preference for a leader to map that leader. This was necessary because maps have been seen to vary depending on the respondent's attitude to the brand (van Rekom, Verlegh \& Slokkers, 2009). Combining maps of those with positive and negative attitudes to a leader would confound the overall results. 
Thus the paper seeks to contribute to our knowledge of how a political campaign affects voter learning, the things that are learned and also how strong this learning was. From this perspective, we are able to comment on the effectiveness of the leaders' campaigns in 2010.

\section{The Leader and Party Brand at the 2010 General Election.}

In studying branding in politics, it is apparent that there are clearly three distinct elements: a trinity with the party as the brand; the politician as its tangible characteristics; and policy as core service offerings (O’Shaughnessy \& Henneberg, 2007). We know that the party as a brand has been seen to have inherent strength because it can produce customer signals that are simple, credible, salient and continuous over long periods of time (Tomz \& Sniderman, 2005). For example Labour's long-standing core brand values are, among others, the reduction of inequality and the promotion of social justice; for the Conservatives it is the championing of the individual and lower personal taxation, etc.

The party leader has always been a significant if not overbearing component of the overall political brand. One reason for this is the ability of the leader to 'personify' meaning symbolically (e.g. by the leader’s looks, age, gender, dress sense, accent and general demeanour). From this, it has been shown that political leaders are like brands in that they have coherent and consistent personalities and wider meaning in the minds of voters (Schneider, 2004; Guzmán \& Sierra, 2009). As more voters have a low involvement with, and are disinclined to learn about, party politics and policies, the leader offers the ability to convey complex meaning that voters can easily assimilate. Thus the leader acts as an important heuristic device that voters use as a short-cut to arrive at decisions at election time based on limited knowledge of parties and policies (Lau \& Redlawsk, 2001).

Academic research about the relative importance of the leader and the party is scant. Davies and Mian (2010) have investigated the link between the two and conclude that, as expected, there is a close relationship between them. However, despite being highly correlated, the two are statistically distinct entities. They also conclude that the leader's reputation influences attitude towards the party more than vice versa. Supporting this, a longitudinal Ipsos MORI poll confirmed that, just prior to the 2010 election and for the first time since 1987, leaders had become as important as policies in attracting voters to a party, with the party itself a long way behind (Mortimore, 2010). As such, we consider the leader and party as being separate, 
highly interlinked brands but with the leader as the senior, 'flagship' brand (John, Loken \& Joiner, 1998) during the 2010 UK General Election.

\section{The 2010 Election Campaign.}

Having argued for leaders as separate, important political brands in their own right, we now consider how, if at all, the brand image of the leaders changed during the last UK General Election Campaign. Brand image is defined as the sum of all associations that consumers have of a brand (Keller, 1993). We focus on the period from just before the election was announced to the election itself with our primary research matching these dates closely.

To contextualise the campaign, the three leaders began it with markedly different political fortunes. The incumbent, Gordon Brown, had been New Labour's Chancellor of the Exchequer since 1997 and Prime Minister since 2007. However, Labour’s popularity was low in 2010, fuelled by such 'events' as the Iraq war and, more recently, the MPs expenses debacle. Also, Brown's handling of the global banking crisis, initially receiving popular support, was superseded by criticism of lack of government regulation of the financial sector. At the same time, stories of Brown's 'bullying' behaviour towards subordinates became prominent in the media. As such the campaign started with Brown leading an unpopular third term government, widely expected to lose the election. The poll of polls at the start of the official campaign (6 ${ }^{\text {th }}$ April, 2010) had the Conservatives, Labour and Liberal Democrats on $39 \%, 31 \%$ and $19 \%$ respectively.

David Cameron was elected to Parliament in 2001 and rose rapidly to the opposition front bench by 2003. After the third demoralising defeat for his party, he became its leader in 2005, delivering an influential speech at the Party Conference promising to make Conservatives feel good about themselves and appeal to a new generation of voters. In subsequent years, he proved effective in restoring his party's image by communicating to the rest of the country that the Conservatives were no longer the 'nasty party'i . This was reinforced with well publicised and carefully planned actions; he cycled to work, had a wind turbine fitted to his house, visited a glacier to show involvement with global warming/green issue and so on. Physically too he was different from Brown, being younger and less dour than the Prime Minister. Thus, at the start of the campaign, the polls suggested that Cameron 
was the Prime Minister in waiting and perversely, the pressure was on him not to lose the election.

Nick Clegg's position on the $6^{\text {th }}$ April was markedly different as few outside of Westminster and Liberal Democrat supporters had a clear image of the man. He was only elected to Parliament in 2005 and after a short period as Liberal Democrat spokesperson on Home Affairs, became leader in 2007. He subsequently suffered from the perennial problem for the leader of the third party in British politics, namely the struggle to get himself known and his ideas across to a largely disinterested electorate and media. For the first time in a UK General Election, he was allowed equal exposure during the leaders' debates, appearing, at first at least, fresh and different from Cameron and Brown. Critically, his party’s popularity rose dramatically after he was perceived to have 'won' the first leaders' debate, and consequently, a 'three horse race' became the sub-text to the election campaign for the first time in post-war Britain.

What follows is a detailed discussion of the likely factors that were influencing voter associations of the three leaders of the main, national political parties in the 2010 campaign. We concentrate on the likely impact of three key influences during the campaign, namely the leaders' debates, paid for advertising and uncontrollable events, with a view to analysing their effect, if any, on the respective leader's overall brand image. We measured leader image at the end of March (just prior to when the election was called) and again on May $6^{\text {th }}$ (election day), 2010. As alluded to, we used brand maps as the means to record voters associations of the leaders at the two periods mentioned.

\section{Voter Learning of Party Leaders - The Leaders’ Debates}

The effect of the campaign on an election has been traditionally viewed as small, with most voters already making their minds up prior to the campaign (Iyengar \& Simon, 2000). One reason may be that, because of the alleged Permanent campaign waged by parties and their leaders, voters will have well established ideas about them and these will remain largely unaffected by the campaign itself (Sparrow \& Turner, 2001). Considering voter learning it has been noted that 'Campaigns are information-rich events. Contrary to the prevailing wisdom, the information they yield is multifaceted, encompassing the candidates' chances of 
winning, their personal traits and mannerisms, and most important, their policy and ideological bearings' (Iyengar \& Simon, 2000, p. 156).

We did not seek to isolate the leaders' debates impact from other potential influences but there is clear evidence that it was a powerful factor. The three 90 minute leaders' debates attracted a total audience of approximately 21 million, a figure underestimating the real impact as the debates were leveraged by intense subsequent news coverage including televised 'highlights' (Zhao \& Chaffee, 1996). Polling evidence reveals that $60 \%$ of respondents thought that, prior to the debates, the latter would be important in influencing how they voted. Subsequently, 23\% acknowledged that they had either changed or considered changing their voting intention as a result of the first debate (Mortimore, 2010).

In terms of the relative performances during the debates, the following table seeks to summarise the evidence. It shows the average of five polls conducted immediately after each debate into the perceived winner of each debate and the overall position (first, second and third) of the leaders.

Table 1. Poll of Polls for Leaders Debates

\begin{tabular}{|l|l|l|l|}
\hline Leader & First Debate & Second Debate & Third Debate \\
\hline Clegg & $1^{\text {st }}(48 \%)$ & 1 st $(34 \%)$ & $2^{\text {nd }}(32 \%)$ \\
\hline Cameron & $2^{\text {nd }}(26 \%)$ & $2^{\text {nd }}(33 \%)$ & $1^{\text {st }}(37 \%)$ \\
\hline Brown & $3^{\text {rd }}(21 \%)$ & $3^{\text {rd }}(27 \%)$ & $3^{\text {rd }}(26 \%)$ \\
\hline
\end{tabular}

Clegg was the clear winner in the first debate and subsequently declined from this highpoint; Cameron performed poorly (against high expectations) in the first debate and subsequently improved to win the last and arguably the most important debate. Brown's poor performance in the first debate only slightly improved in subsequent ones. However, Curtice (2010) notes that in the last debate, 73\% of Conservatives thought Cameron had won, 64\% of Lib Dems thought Clegg won and 68\% of Labour supporters though Brown had won. This suggests that over the debates, there was a positive partisan bias, suggesting that the debates positively reinforced supporters' image of their preferred leader.

Given that each debate had a specific core focus (domestic affairs, foreign affairs and the economy in that order - see BBC (2010) for the sub themes that were discussed), and that 
these were meant to reflect the 'important' policy issues facing the electorate, we can use our maps to gauge if a) any of these policies were introduced into supporters maps and or b) whether policies became stronger or weaker within the maps over the campaign. We accept that any changes we identify may have been caused by the debates or other external influences over the campaign, including political advertising which we consider next.

\section{The Effect of Party Political Advertising}

It has been noted that UK General Election campaigns have on balance become more negative including the use of personal attack advertising aimed at the leaders of opposition parties. This negativity has exacerbated the already low levels of voters trust held in parties and their leaders (Dermody \& Hanmer-Lloyd, 2005). This apparently counter-productive strategy is explainable by the enduring belief that negative information about opponents is more influential than positive candidate information (Pinkleton, 1997). A re-analysis of poll data from six US presidential elections has cast doubt on this (Klein \& Ahluwalia, 2005) and concluded that candidate preference is a major moderating effect. In fact, negativity only appeared to have a significant effect on those who already had a negative attitude to a politician. This so called 'motivational' conceptualisation of negativity in politics is based on biased processing of information through various mechanisms to avoid cognitive dissonance such as source derogation (Ahluwalia, 2000).

To prevent compounding the negativity effect by considering maps of those with a preference and antipathy to a leader, we asked respondents to map only their preferred leader. An implication of this is that they are likely to already have a positive set of associations of their preferred leader in their mental maps. Given the recent evidence on the effect of negative campaigning we expect that such negativity will be filtered out or explained away such that no effect will be evident in the leaders' maps.

\section{The Impact of the Gillian Duffy Event on Gordon Brown's Image.}

When asked what blows a government off course, MacMillan famously replied 'Events, dear boy, events'. During the 2010 campaign, Gordon Brown, whilst still being taped, referred to a member of the public he had just talked with (Gillian Duffy) as a bigot. It was the most important uncontrolled event of the campaign and generated massive negative media coverage. ${ }^{\text {ii }}$ There was, prima facie, reason to expect that voters would apportion blame to 
him as a result. Attribution theory (Folkes, 1984), has been used previously to analyse credit or blame apportionment from political events (Smith, 2005). In this case, Brown was the cause of the event (its locus), had control over it and such action was not the normal state (i.e. it's not normal to bad-mouth electors). As such, negative attribution conditions existed (Weiner, 1986). However, image repair discourse suggests mitigation strategies for politicians (Benoit \& McHale, 1999). Brown first used 'defeasibility' (incorrect information) as a rhetorical device, arguing he had mis-heard Mrs. Duffy’s comments about immigrants. He followed this with 'corrective action' by visiting Mrs. Duffy to explain himself. As the furore mounted he finally adopted the 'mortification' device, apologising and saying he was very sorry (Wintour \& Curtis, 2010).

In terms of the effect of 'Duffygate' on Brown the literature suggests he was liable for blame apportionment but apologia may have negated the effect. We therefore analyse Brown's map before and after the event to see if it had become a voter association of him and whether it had become a negative association. There is no reason to think that any 'event' will be present in the other leaders' maps.

\section{Leader Brand Image and Brand Equity During the Campaign}

According to Keller (1993, p. 1), 'A brand is said to have positive (negative) customer-based brand equity when consumers react more (less) favourably to an element of the marketing mix for the brand than they do to the same marketing mix element when it is attributed to a fictitiously named or unnamed version of the product or service'. In politics, such equity would mean voters viewing a leaders' debate or Party Election Broadcast more (less) positively because he/she already had a positive (negative) view of that party.

It has been argued that the associations that consumers have of a political brand are key to the way that voters interpret new information and how they behave towards the brand (French \& Smith, 2010), though this has not been investigated at an election and at different stages of an election. However, brand associations are not all of equal importance or positive and as such affect equity differently. Thus brand association strength, favourability and uniqueness have been identified as criteria for brand image strength and eventually brand equity (Keller, 1993). Brand image strength (henceforth BIS) is thus influenced by the number of associations the leader brings to mind; more is better than less as this allows greater potential 
from spreading activation to other associations (Krishnan, 1996). Clearly, it is also important that the associations are favourable rather than negative for enhanced brand image and equity. Lots of negative associations will lead to low or even negative brand equity. Uniqueness relates to associations not shared with other leaders, making such associations a potential source of differentiation. Political brands have been seen to be quite different from each other in that they have a large number of unique associations (French \& Smith, 2010). For example, Brown is likely to be associated with Labour, the colour red, being Prime Minister, having been Chancellor, being older - associations not shared with Cameron and Clegg. In the leaders' maps that follow (Figures 1, 2 and 3), no association is shared between party leaders, reflecting their uniqueness compared to each other.

To measure leader BIS, therefore, we need to incorporate the above criteria. In addition we compared these measures at the beginning and end of the campaign to determine if their image (and concomitant brand equity) had increased or decreased over the campaign.

\section{Research Propositions}

The rest of the paper seeks to uncover the perceived leader brand effects that occurred during the UK 2010 General Election. From the preceding review of the branding, voter behaviour and campaign effects literature, we are directed towards the following research areas, provided as propositions for testing.

Based on the work of Iyengar and Simon (2000) that campaigns do have an effect on voter knowledge of political issues:-

P1a) There will be a significant increase in the number and strength of leader associations as reflected in their brand maps at the start and end of the election campaign.

P1b) There will be evidence of learning about policies and particularly those which relate to the themes of the campaign

The research of Klein and Ahluwalia (2005) suggests that the effect of negative advertising has been exaggerated. Given that there will be positive elements of all campaigns and we are considering respondents who are likely to be more amenable to positive/reinforcing information and more likely to filter out negative information, we propose that there will be a positive effect on the leaders' maps. Hence:- 
P2) There will be a significant improvement in perceived favourability of leaders as measured by their brand associations over the campaign.

We have seen that brand image is determined by the overall nature of a brand's associations and that we expect these to grow in number and favourability over the campaign. It therefore follows that we can also expect to see an overall improvement of the leaders' brand image during the campaign. As brand image is a key component of a brand's equity, the latter should be enhanced by the campaign too.

P 3) There will be a significant positive effect on leader brand image from the campaign, causing enhanced leader BIS.

Given the conflicting attribution and apologia literature discussed, we propose that:P4a) There will be no specific evidence of the Duffy affair in Brown's final brand map (i.e. after the affair took place).

P4b) There will be no general dilution of Brown's brand image from the affair.

Next we outline the nature of brand maps and the methodology for their construction.

\section{Developing Brand Maps for the Party Leaders.}

Recently, a practical means of producing mental maps of brands has emerged. The Brand Concept Mapping approach of John, Loken, Kim and Basu Monga (2006) is a well tested method for the efficient production of mental maps, based on the cognitive psychology/HAM conceptualisation referred to previously. The maps are drawn by individual consumers quickly and in enough quantity, with proven validity and reliability, to allow confidence in the resulting map for a given brand. It is this approach that we have adopted for measuring the mental maps of the party leaders just prior to the campaign launch and on election day (May 6 $\left.{ }^{\text {th }}, 2010\right)$.

We followed John et al.’s (2006) protocol for developing Brand Concept Maps (henceforth BCMs). Rather than repeat the methodology used to create the maps in detail (see John et al. 2006 for this), we focus on showing how we a) developed BCMs of the three leaders, and b) 
analysed the maps to address the research propositions that we have developed from the literature.

The BCM approach uses a stimulus to trigger memory about a brand. The stimulus used in this research was the brand name, i.e. Gordon Brown, David Cameron and Nick Clegg. The research was based on a sample of two discrete groups of undergraduate students taught by the authors at an English University, one for the elicitation stage $(\mathrm{N}=141)$ and one for the actual mapping stage $(\mathrm{N}=169)$. This convenience sample, though not representative of the wider electorate, is reflective of an important segment of the wider voting population, namely, first time voters. Also, their educational base/intelligence allows for their assimilation of brand knowledge prior to and during the campaign, thus leading to well developed BCMs for subsequent analysis.

The first step in BCM research is the Elicitation phase wherein the first cohort were asked to write down the associations (unprompted) that came to mind when they thought of their own personal preference of leader in the forthcoming election. This produced an unprompted listing of associations for Brown, Cameron and Clegg. This list was then reduced by removing associations mentioned by very few respondents (4 or less).

The second, Mapping phase entailed using a different subset of the student population. They were shown an existing brand map of the VW Beetle to instruct them on how to construct a brand map. ${ }^{\text {iii }}$ They were next asked to identify the leader of the party they were most inclined to support at the election and were then directed to the associations of their favoured party leader, as derived from the Elicitation stage. From these they were asked to construct their own map for their chosen leader. Respondents were also told that could add their own associations. Participants were asked not only to choose those associations they thought relevant but also to link them together. When this was complete, respondents were asked to indicate the strength of the link between associations using single, double or triple lines. Finally, they were instructed to indicate how they viewed favourability/unfavourability by placing either a plus or a minus sign beside each association; if they had neutral feelings, then they were instructed to leave the association unmarked.

At the third, Aggregation stage, the individual brand maps were used to generate a single brand consensus map for each leader, again following John et al's (2006) mapping protocol. 
With the three leaders' maps, aggregation was done by a) identifying the (first and secondorder) brand associations that feature on the majority of individual maps; b) adding (firstorder) associations to the map that were linked to the party more often than not; c) adding the remaining (second-order) associations by linking them to the already positioned first-order associations; d) adding (tertiary) associations to the map - these are included due to high frequency links to first and or second-order associations and e) calculating the average "weight" for each link, based on the weights in the individual maps. This produced the leaders' maps that are provided as Figures 1 to 3 below. First-order associations are shown as shaded ovals, second-order as unshaded ovals with a solid outline and tertiary as unshaded ovals with dashed outlines.

As two maps were produced for each leader at different points in the campaign, the three stages were replicated at the end of the campaign. For the second set of maps we used a new but matched respondent group of students for elicitation to allow new associations to emerge from the campaign. The new list of associations was provided to construct the second set of maps from the same group of respondents as the first mapping exercise. They were again asked to produce a map for the party leader they were most inclined to vote for. As such some respondents 'switched' between their first and second map. We did not seek to isolate these 'switchers' as we were concerned, not with individual, but group level views on the leader they support as the campaign unfolded.

TAKE IN FIGS 1, 2 AND 3 HERE.

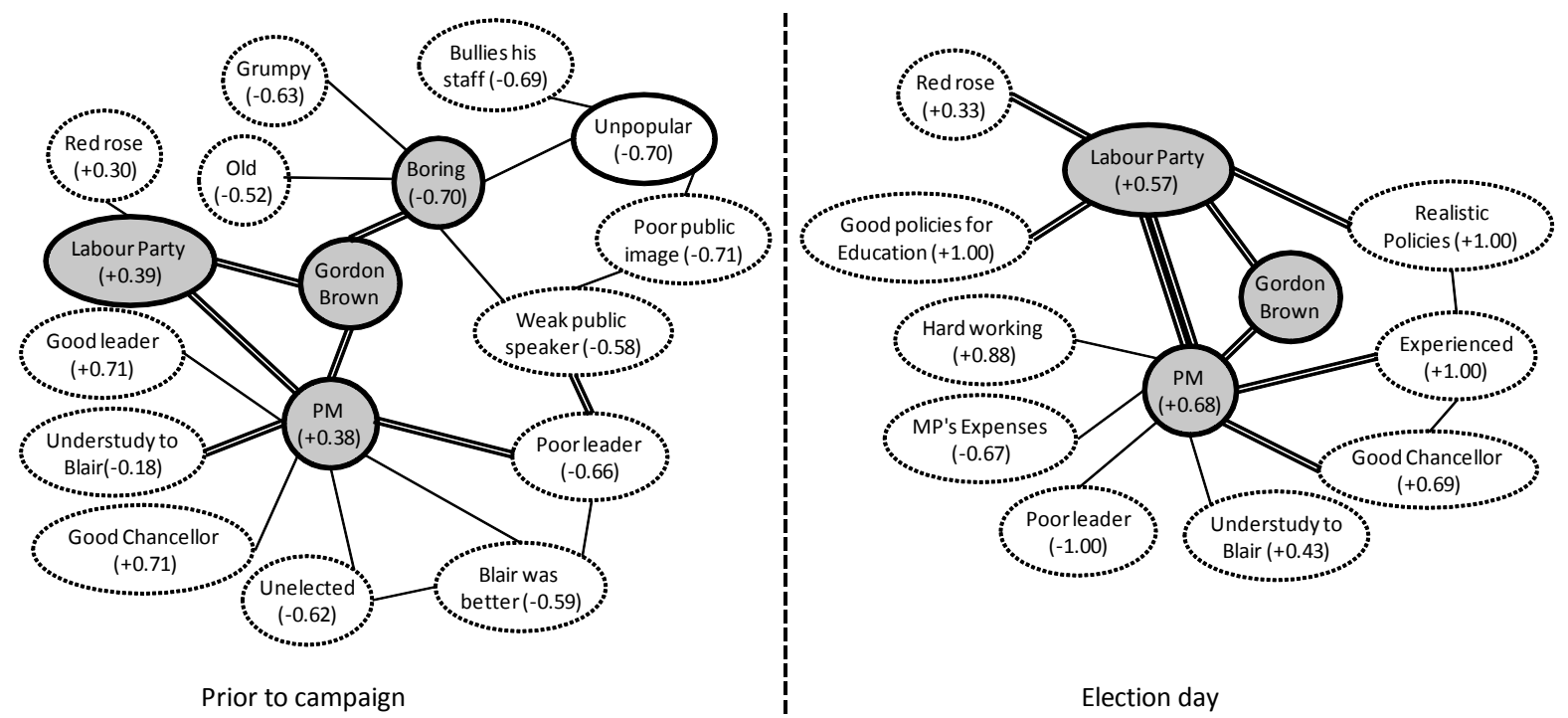


Figure 1. Brand Concept Maps of Brown by Labour Supporters.
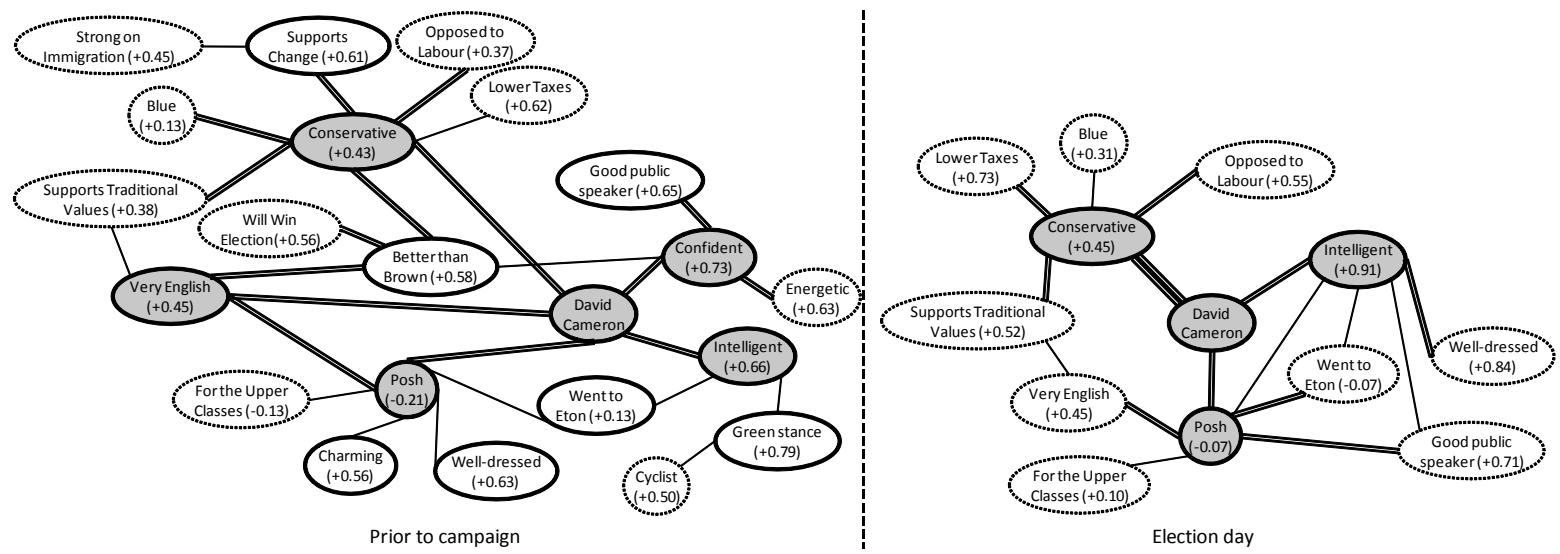

Figure 2. Brand Concept Maps of Cameron by Conservative Supporters.
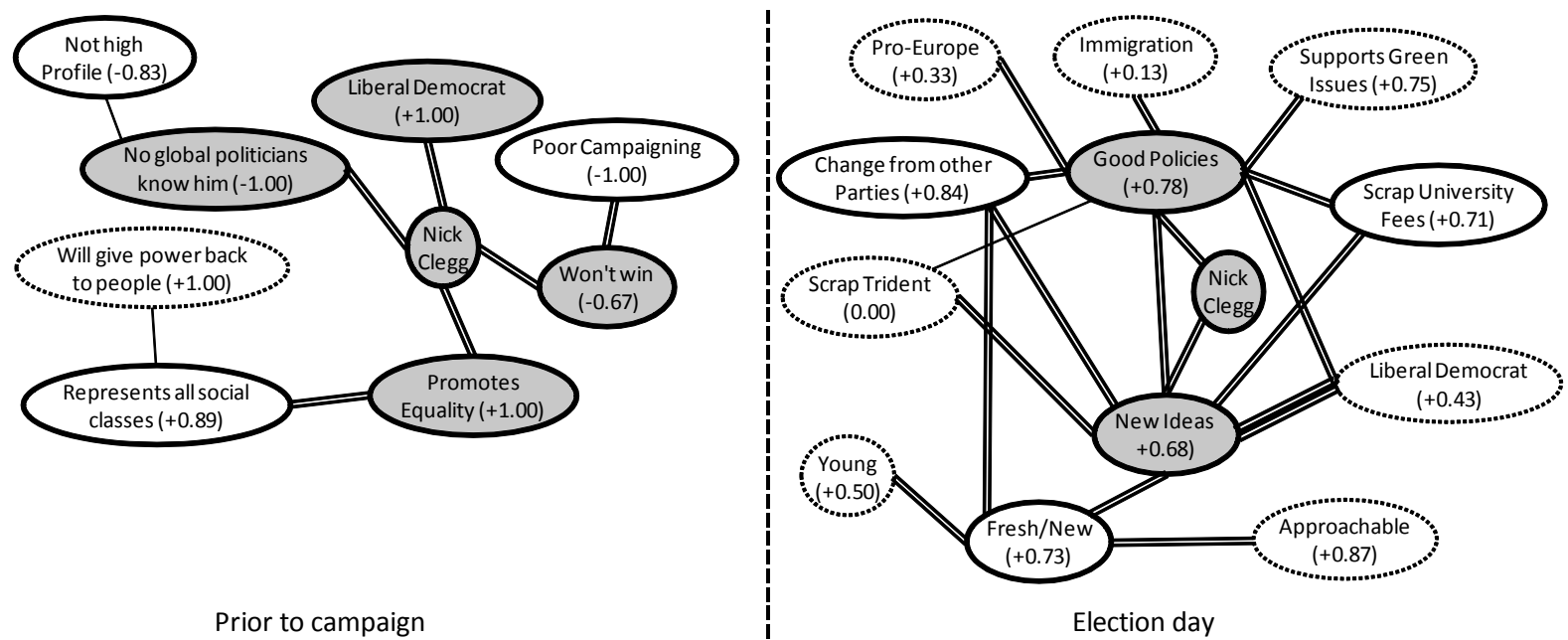

Figure 3. Brand Concept Maps of Clegg by Liberal Democrat Supporters.

\section{Results}

We will now consider each of the research propositions developed earlier.

P 1a) There will be a significant increase in the number and strength of leader associations as reflected in their brand maps at the start and end of the election campaign.

To address this we analysed the BCMs as shown in the following Tables (2 and 3).

\begin{tabular}{|l|l|l|l|l|l|}
\hline & & \multicolumn{4}{|c|}{ Number of associations } \\
\hline Leader & & First-order & Second-order & Tertiary & Total \\
\hline
\end{tabular}




\begin{tabular}{|l|l|l|l|c|c|}
\hline \multirow{3}{*}{ Brown } & Pre-campaign & 3 & 1 & 12 & 16 \\
\cline { 2 - 6 } & Post-campaign & 2 & 0 & 9 & 11 \\
\hline \multirow{3}{*}{ Cameron } & Pre-campaign & 5 & 7 & 9 & 21 \\
\cline { 2 - 6 } & Post-campaign & 3 & 0 & 9 & 12 \\
\hline \multirow{2}{*}{ Clegg } & Pre-campaign & 4 & 3 & 1 & 8 \\
\cline { 2 - 6 } & Post-campaign & 2 & 3 & 7 & 12 \\
\hline
\end{tabular}

Table 2. Number of associations (excluding the leader) on each map.

\begin{tabular}{|c|c|c|c|c|c|c|}
\hline & & \multicolumn{4}{|c|}{ Number of links } & \\
\hline Leader & & Single & Double & Triple & Total & Sum of weights ${ }^{\text {iv }}$ \\
\hline \multirow{2}{*}{ Brown } & Pre-campaign & 14 & 7 & 0 & 21 & 29.9 \\
\hline & Post-campaign & 6 & 7 & 1 & 14 & 24.5 \\
\hline \multirow{2}{*}{ Cameron } & Pre-campaign & 11 & 15 & 0 & 26 & 37.4 \\
\hline & Post-campaign & 7 & 9 & 1 & 17 & 27.1 \\
\hline \multirow{2}{*}{ Clegg } & Pre-campaign & 2 & 6 & 0 & 8 & 13.9 \\
\hline & Post-campaign & 2 & 16 & 1 & 19 & 34.1 \\
\hline
\end{tabular}

Table 3. Number of links on each map.

As can be seen in Table 2, the number of associations for both Brown and Cameron dropped during the campaign. Only Clegg managed to increase the number of associations. This pattern (Brown and Cameron dropping, Clegg increasing) was also repeated when analysing the number of links and total link weight on each of the maps (see Table 3).

As there is not a consistent increase in number of associations and the strength of their links, Proposition 1a) is not supported.

P1b) There will be evidence of learning about policies over the period of the campaign and that these will reflect the policy themes of the leaders' debates.

There is no general support for this proposition from the maps (see Figures 1, 2 and 3). Put in context, thirty policy issues were covered by the three leaders' debates (BBC, 2010). 
Brown's Election Day map reveals only one policy, 'Good Policies for Education', and this is a tertiary (i.e. lower importance) association. He had no policies at all in the first map. Cameron’s Election Day map also reveals only one policy, 'Lower Taxes', again at the tertiary level. Indeed, over the campaign he lost policy associations ('Green stance' and 'Strong on Immigration' associations which were present in his first map). Only with Clegg is there clear evidence that policies have become associated with the leader during the campaign. In his first map, 'Promotes Equality' is a core association for Clegg. In his second map, 'Good Policies’ is a core association that links with five specific policies, namely, ‘Scrap University Fees’, ‘Supports Green Issues’, ‘Immigration’, ‘Pro-Europe’ and 'Scrap Trident'.

P2) There will be a significant improvement in perceived favourability of leaders as measured by their brand associations over the campaign.

\begin{tabular}{|l|c|c|c|c|c|c|c|}
\hline & \multicolumn{3}{|c|}{$\begin{array}{c}\text { Average } \\
\text { favourability }\end{array}$} & \multicolumn{2}{c|}{$\begin{array}{c}\text { Standard } \\
\text { deviation }\end{array}$} & \multicolumn{2}{c|}{$\begin{array}{c}\text { Number of } \\
\text { associations }\end{array}$} \\
\hline Leader & Before & After & Change & Before & After & Before & After \\
\hline Brown & -0.256 & 0.448 & $0.704^{*}$ & 0.531 & 0.646 & 16 & 11 \\
\hline Cameron & 0.453 & 0.453 & 0.000 & 0.262 & 0.318 & 21 & 12 \\
\hline Clegg & 0.049 & 0.562 & $0.514^{* *}$ & 0.929 & 0.274 & 8 & 12 \\
\hline
\end{tabular}

${ }^{*}$ Significant at $\mathrm{p}<0.01,{ }^{* *}$ Significant at $\mathrm{p}<0.1$

Table 4. Summary of favourability scores.

Table 4 clearly shows that favourability of the associations improved most significantly for Brown, significantly for Clegg and stayed the same for Cameron. More specifically, Brown's associations were on average negative at the outset and became positive by the end. Cameron had high favourability at the outset and maintained this. Clegg's associations became more favourable over the campaign - so much so that he finished the campaign with the most favourable associations of all the leaders. As such we find partial support for the proposition. 
P 3) There will be a significant positive effect on leader brand image from the campaign, causing enhanced leader BIS.

As we discussed previously, brand image is a function of the number, strength of links and favourability of the associations with the brand. We have also noted that brand associations on the leaders' maps are unique. As such, we accept uniqueness between leader maps and focus on the other components that affect BIS as previously identified. By measuring brand image thus, this approach incorporates important elements of brand equity as identified by theory.

A measure that integrates these is identified below:-

Brand Image Strength $=$ Normalised Association Score $\mathrm{x}$ Average Favourability $\mathrm{x}$ Normalised Links Score

Normalised Association Score $=$ Number of Associations $/$ Maximum Number of Associations over all maps

Normalised Links Score $=$ Sum of Weight of Links $/$ Maximum Sum of Weight of Links over all maps

By normalising, BIS will lie somewhere between -1 (completely negative) and +1 (completely positive) and hence allow us to compare the image of leaders at a point and over time.

\begin{tabular}{|l|l|c|c|c|c|c|c|}
\hline & Leader & Ass'ns & $\begin{array}{c}\text { Norm. } \\
\text { Ass'ns }\end{array}$ & $\begin{array}{c}\text { Ave. } \\
\text { Fav }\end{array}$ & $\begin{array}{c}\text { Sum of } \\
\text { Links }\end{array}$ & $\begin{array}{c}\text { Norm. } \\
\text { Links }\end{array}$ & BIS \\
\hline \multirow{3}{*}{ Before } & Brown & 16 & 0.76 & -0.256 & 29.9 & 0.80 & -0.16 \\
\cline { 2 - 8 } & Cameron & 21 & 1.00 & 0.453 & 37.4 & 1.00 & 0.45 \\
\cline { 2 - 8 } & Clegg & 8 & 0.38 & 0.049 & 13.9 & 0.37 & 0.01 \\
\hline \multirow{3}{*}{ After } & Brown & 11 & 0.52 & 0.448 & 24.5 & 0.66 & 0.15 \\
\cline { 2 - 9 } & Cameron & 12 & 0.57 & 0.453 & 27.1 & 0.72 & 0.19 \\
\cline { 2 - 9 } & Clegg & 12 & 0.57 & 0.563 & 34.1 & 0.91 & 0.29 \\
\hline
\end{tabular}

Table 5. Brand Image Strength measure for party leaders 
With this measure of the brand image from BCMs (see Table 5), Brown is seen to have had a negative image at the outset but, by the end of the campaign, negative associations had become less important and or disappeared altogether whilst new, more positive associations had developed. As a result, on election day he had positive brand image amongst his supporters. Cameron started the campaign with the strongest brand image measure and whilst still positive, this fell back by the end of the campaign. Clegg began with a neutral image and ended with the most positive image measure of the three leaders. In terms of overall change brought about by the campaign, Brown's change was the most, even though his image was the lowest of the three on election day. Given this interesting but not uniform experience, the proposition is not supported; BIS did develop for Clegg and Brown but declined for Cameron.

P4a) There will be no specific evidence of the Duffy affair in Brown's final brand map (i.e. after the affair took place).

'Eyeballing' the two maps for Brown (Figure 1) answers this clearly; there was no evidence of a Duffy effect. Indeed, the 'Bullies his staff' association in his first map is not present in the second as a more positive attitude towards Brown developed as the election neared. It should be noted that the association 'Gillian Duffy' and 'Bullies his staff' were available to respondents in the second mapping exercise.

P4b) There will be no general dilution of Brown's brand image from the affair.

Although we are not able to isolate the Duffy affair, it is evident from the favourability and BIS scores for Brown that his image improved as the campaign went on. Without the Duffy affair this improvement might have been stronger of course, but the absence of any related associations does not support this interpretation.

Taken together, proposition $4 \mathrm{a}$ and $4 \mathrm{~b}$ are supported as the Duffy affair had little identifiable negative effect on Brown amongst his supporters.

\section{Discussion}

The maps have provided us with a great deal of information about how voters' associations of preferred leaders changed over a campaign. However, the changes were not always as 
expected. On reflection, our propositions tacitly assumed that voters had the same or similar knowledge of their preferred leader and thus, learning effects would be uniform. In practice they were not; Clegg, being less well known, had much greater potential to 'grow' as a brand through the election. Cameron had a harder task as his associations were well established and positive and he had the difficult task of holding things at this high level whilst both of his opponents sought to attack him (most notably in the first leaders' debate). Overall, using our brand measures, he was successful in doing this. Brown too was not going to be affected the same as others as he was not expected to campaign well and was unpopular at the outset even with those who preferred him.

With regards proposition 1a, we are faced by an interesting phenomenon; the narrowing of Brown and Cameron's maps and the expansion of Clegg's. The latter is easy to understand given Clegg's access to greater media coverage than is available to a third party leader during a Parliament. It would appear that Lib Dem supporters were unclear about Clegg (i.e. as reflected in his first map) and that they were filling this void by learning about him over the campaign as new information was assimilated into memory and activated when the last map was produced.

However, Clegg's success should not have caused a reduction in associations and links for the main party leaders. The narrowing of the maps for Brown and Cameron was not expected. One explanation forwarded by the literature is that forgetting of brand associations can take place. This can be brought about by ‘interference’ created by additional new brand information being assimilated (Keller, Heckler \& Houston, 1998). Another possibility is that voters are acting as cognitive misers (Simon, 1957) using a few associations as 'heuristic' devices to act as a short-cut to decision making. As the election neared, they concentrate on a narrower group of ideas, with other, now less important associations becoming less well recalled.

With regards proposition 1b, it is interesting how few policy associations were evident in the maps. Clegg added five policy associations which were part of a wider, steep learning curve about him, a less well known brand. For Brown and Cameron policies were not evident and these did not develop through any campaign communications (such as election broadcasts and the leaders' debates). As such, for the supporters of Brown and Cameron in this group of voters at least, they could not be using the leader's policies to inform their preference and 
likely voter behaviour. The leader as heuristic device for policies is perhaps operating here. Another possible explanation is that voters don't really think that a leader will implement policy as they promise and thus don't bother to associate them strongly with the leader. Clegg may have managed to overcome this barrier by his novelty and ability to position himself as the outsider to mainstream party politics. Brown's weakness as a leader is reflected in that, despite having been in government for 13 years, he had failed to become associated with any policies beyond 'Good policies for Education'.

With regards, proposition 2, as expected, both Brown and Clegg's associations became more favourably perceived. Cameron's stayed as they were and we speculate whether it is harder to enhance already favourable associations of a popular leader than those which are unfavourable or neutral.

The findings on BIS changes, relating to proposition 3, are particularly revealing. Cameron began with a strong image which was diluted by the campaign. It is tempting to think that Cameron supporters were less impressed with his performance because they had high expectations and because Clegg apparently stole his crown as the best communicator. Clegg had the most to gain from the campaign as for the first time he had almost parity in media coverage with the other two leaders. The maps and BIS measures show this learning and image building effect clearly. Conversely, we can see how Brown's image became more focused but more positive as the campaign progressed, indicating that he, whilst not 'winning' the campaign had steadied the ship as far as supporters were concerned. Cameron's experience was also to be expected. The leader who is expected to win and perform the best at the leaders' debates can only confirm that expectation or underperform. Clegg's first debate set the campaign alight and prevented the campaign becoming a victory procession for the Tories. Cameron's subsequent leader's debates were better and culminated in him 'winning' the final one. With such a campaign backdrop, a decline followed by consolidation in his map is understandable.

Regarding propositions 4a and 4b, Brown's experience with the Duffy affair has been seen to not have affected his supporters maps at all; in fact the opposite. His first map included a 'Bullies his staff' association. This disappeared with the general improvement in the second map and, although the association Gillian Duffy was on the elicitation list, not enough respondents included it on a map for it to show on the aggregate map. We can speculate 
whether his 'apologia' succeeded or that the respondents had 'filtered out' the information but it did not have much bearing for the group of Labour supporters.

\section{Conclusion, Limitations and Further Research}

This special edition of the journal sets out, amongst other things, to evaluate perspectives on how the use of marketing is evolving plus its prospects for future use in British General elections. In this paper we have supplied a new perspective on how to analyse the impact of a campaign on voters using the associations that voters hold of party leaders and from which their voting decisions will be influenced. It has the prospect of further application as the targeting of 'important' groups/segments provides focus for future mapping activity by both academics and, given its practicality, party researchers also.

More specifically, the mapping approach provides a new avenue for positioning research by measuring the effectiveness of brand identity building when compared with the actual image change within voter segments - and how these change over time in relation to brand strategy. BCM thus promises to be a practical tool for campaign managers that may be used widely or more likely in a targeted way (at floating voters in marginal constituencies for example). Showing how the method works in the electoral context, plus evidence on campaign negativity, BIS measurement of leaders plus the impact of events are important contributions and point the way for further research in political brands and campaign effects. Longitudinal BCM analysis also allowed us to analyse the success or otherwise of a campaign on voter learning about a leader. It has the potential therefore to be used in future campaigns to better understand the leader and party’s brand image to shape campaign strategy and analyse speedily the success or failure of specific tactics.

However, the preceding results and discussion section is limited by the fact that, given the convenience nature of our sample, we are unable to generalise from these findings. The results and discussion section also highlighted the limits of the mapping approach as a standalone research tool. It is powerful in charting brand image and how this changes over time. It is not able to explain why these changes have occurred. One way of addressing this is to adopt a mixed approach wherein brand mapping is supplemented with parallel qualitative research to ask voters, post hoc, to explain the influences and experiences that generated 
changes to their maps over time. Such an approach can be used to research further those unexpected results that we witnessed in our research.

Considering further research, we acknowledge that some explanations, forwarded in the discussion, remain speculative of why some propositions were not supported by the findings. Thus, the narrowing of Brown and Cameron's maps over the campaign, the lack of policy associations identified on maps and the role of apologia in offsetting damaging 'events' are areas in themselves for further explanatory research. It is also apparent that, had we more space, we could have focused on other interesting ways of analysing the maps. For example, we have not really considered what the maps tell us of the relative importance of 'brand personality' dimensions for the leaders in terms of their own maps and as compared to each other. The mapping process thus offers a different means of analysing leader personality than the a priori personality scales approach currently used in political branding research (Smith, 2009; Guzmán \& Sierra, 2009).

Herein we focused on the importance of (or lack of) policies in the leaders' maps. We could just as easily have considered the relative importance of the 'Party' association within the leaders’ maps. It is, for example, apparent that the Conservative party and Labour party are important associations for Cameron and Brown; both parties being core associations linked to their respective leader. By comparison, on election day, the Liberal Democrat party was only a tertiary association for Clegg. There is thus the potential to use more sophisticated measurement to analyse this relationship within maps.

By way of conclusion, within this paper we have analysed the effect that the 2010 Election Campaign had on the leaders of the three main, national parties. BCMs offer great potential for tracking voter groups (e.g. core supporters, floating voters etc.) during campaigns. It can also be used to track changes over a Parliament or whilst important national issues are played out (such as the Iraq war, coalition politics and electoral reform, etc.). The BCM approach can identify clearly and quickly the mental map that voters carry for leaders and their parties. As such, they can reveal the difference between what campaign managers want (i.e. desired political brand identity) and what voters will let them have (actual political brand image as reflected in brand maps). The challenge party strategists face has not changed; they still need to develop a campaign which creates an image in the minds of 'important' voter groups 
which matches their desired brand identity. The BCM approach now offers a useful tool for tracking their success in this task.

\section{References}

Ahluwalia, R. (2000). Examination of psychological processes underlying resistance to persuasion. Journal of Consumer Research, 27, 217-232.

Anderson, J. R. (1983). The architecture of cognition. Cambridge: Harvard University Press.

BBC, (2010, August). Prime ministerial debates - programme format. BBC Website.

Retrieved from http://www.bbc.co.uk/blogs/theeditors/pm_debates_programme_format.pdf

Benoit, W. L. and McHale, J. P. (1999). Kenneth Starr's image repair discourse viewed in 20/20. Communication Quarterly, 47, 265-280.

Curtice, J. (2010, May). Voters judged the debates based on their prejudices. The Independent. Retrieved from http://www.independent.co.uk/opinion/commentators/johncurtice-voters-judged-the-debates-based-on-their-prejudices-1959601.html

Davies, G. and Mian, T. (2010). The reputation of the party leader and of the party being led. European Journal of Marketing, 44, 331-350.

de Groot, A.M.B. (1989). Representational aspects of word imageability and word frequency as assessed through word association. Journal of Educational Psychology: Learning Memory and Cognition, 15, 824-845.

Dermody, J. and Hanmer-Lloyd, S. (2005). Promoting distrust? A chronicle of the 2005 British General Election advertising campaigns. Journal of Marketing Management, 21, 1021-1047.

Dobni, D., \& Zinkhan, G. M. (1990). In search of brand image: A foundation analysis. Advances in Consumer Research, 17, 110-119. 
Folkes, V. (1984). Consumer reactions to product failure: An attributional approach. Journal of Consumer Research, 10, 398-409.

French, A.P. and Smith, I.G. (2010). Measuring political brand equity: A consumer oriented approach. European Journal of Marketing, 44, 460-477.

Guzmán, F. and Sierra, V. (2009). A political candidate’s brand image scale: Are political candidates brands. Brand Management, 17, 207-217.

Harris, P. and Lock, A. (2001). Establishing the Charles Kennedy brand: A strategy for an election the result of which is a foregone conclusion. Journal of Marketing Management, 17, 943-956.

Iyengar, S. and Simon, A. F. (2000). New perspectives and evidence on political communication and campaign effects. Annual Review of Psychology, 51, 149-169.

John, D.R., Loken, B. and Joiner, C. (1998). The negative impact of extensions: Can flagship products be diluted? Journal of Marketing, 62, 19-32.

John, D.R., Loken, B., Kim, K. and Basu Monga, A. (2006). Brand concept maps : A methodology for identifying brand association networks. Journal of Marketing Research, 43, 549-563.

Kavanagh, D. (1995). Election campaigning: The new marketing of politics, Oxford, UK: Blackwell.

Keller, K.L. (1993). Conceptualizing, measuring, and managing customer-based brand equity. Journal of Marketing, 57, 1-22.

Keller, K.L., Heckler, S.E. and Houston, M.J. (1998). The effects of brand name suggestiveness on advertising recall. Journal of Marketing, 62, 48-57. 
Keller, K.L. (2002). Branding and brand equity. In B. A. Weitz and R. Wensley (Eds.), Handbook of marketing (151-178). Thousand Oaks, CA: Sage.

Klein, J. G. and Ahluwalia, R. ( 2005). Negativity in the evaluation of political candidates. Journal of Marketing, 69, 131-142.

Krishnan, S.H. (1996). Characteristics of memory associations: A consumer-based brand equity perspective. International Journal of Research in Marketing, 13, 389-405.

Lau, R. R. \& Redlawsk, D. P. (2001). Advantages and disadvantages of cognitive heuristics in political decision making. American Journal of Political Science, 45, 951-971.

Mortimore, R. (2010, May). That election in figures. The Coventry Conversation, Retrieved from http://www.scribd.com/The-Election-in-Numbers-Roger-MortimoreMORI/d/31301507.

Needham, C. (2005). Brand leaders: Clinton, Blair and the limitations of the permanent campaign. Political Studies, 53, 343-361.

Needham, C. (2006). Brands and political loyalty. Brand Management, 13, 178-187.

O’Shaughnessy, N. J. and Henneberg, S.C. (2007). The selling of the President 2004: A marketing perspective. Journal of Public Affairs, 7, 249-268.

Pinkleton, B. E. (1997). The effects of negative comparative political advertising on candidate evaluations and advertising evaluations: An exploration. Journal of Advertising, 26, 19-29.

Scammell, M. (2007). Political brands and consumer citizens: The rebranding of Tony Blair. The ANNALS of the American Academy of Political and Social Science, 611,176 -192.

Schneider, H. (2004). Branding in politics - manifestations, relevance and identity-oriented management. Journal of Political Marketing, 3(3), 41-67. 
Simon, H. (1957). Models of man: Social and rational. New York: Wiley.

Smith, I.G. (2001). The 2001 General Election: Factors influencing the brand image of political parties and their leaders. Journal of Marketing Management, 17, 1058-1073.

Smith, I.G. (2005). Politically significant events and their effect on the image of political parties: A conceptual approach. Journal of Political Marketing, 4(2/3), 91-114.

Smith, I.G. (2005). Conceptualising and testing brand personality in British politics. Journal of Political Marketing, 8, 209-232.

Smith, G. and French, A. (2009). The political brand : A consumer perspective. Marketing Theory, 9, 209-226.

Sparrow, N. and Turner, J. (2001). The permanent campaign - The integration of market research techniques in developing strategies in a more uncertain political climate. European Journal of Marketing, 35, 984 - 1002.

Teichert, T.A. and Schöntag, K. (2010). Exploring consumer knowledge structures using associative network analysis. Psychology \& Marketing, 27, 369-398.

Tomz, M. and Sniderman, P.M. (2005). Brand names and the organisation of mass belief systems. Retrieved from Stanford University website:

http://www.stanford.edu/ tomz/working/TomzSniderman2005.pdf

van Rekom, J., Verlegh, P.W.J. and Slokkers, R. (2009). The owner's edge: Brand ownership influences causal maps. Journal of Business Research, 62, 339-344.

Weiner, B. (1986). An attributional theory of motivation and emotion. New York: Springer/Verlag.

White, J. and de Chernatony, L. (2002). New Labour: A study of the creation, development and demise of a political brand. Journal of Political Marketing, 1(2/3), 45-52. 
White, M. and Perkins, A. (2002, October). 'Nasty party’ warning to Tories. the guardian.

Retrieved from http://www.guardian.co.uk/politics/2002/oct/08/uk.conservatives2002

Wintour P. and Curtis, P. (2010, April). Gordon Brown 'penitent' after bigot gaffe torpedoes election campaign. the guardian. Retrieved from

http://www.guardian.co.uk/politics/2010/apr/28/gordon-brown-penitent-bigot-gaffecampaign

Zhao, X. and Chaffee S.H. (1996). Campaign ads versus television news as information sources. Public Opinion Quarterly, 59, 41-65.

\footnotetext{
i At the 2002 Conservative party conference at Bournemouth, the Chairman, Theresa May, attacked her own party as "just plain unattractive” and "the nasty party”. She highlighted the party’s “demonising” of minorities as having positioned it too narrowly and unsympathetically for large swaths of the electorate (White and Perkins 2002).

${ }^{\text {ii }}$ Other uncontrolled events occurred. Cameron was widely decried for his poster that carried what looked like an airbrushed photo' of him. Although not of the same level as the Duffy incident we did check his last brand map and confirmed that it did not appear .

iii This brand map was the same as used by John et al. (2006), amended to make more relevant to the sample.

iv The actual (unrounded) average weights for all links on a given map were used to increase accuracy.
} 